\title{
Analysis on the Solar Technology Application in Ecological Building
}

\author{
Aiping Deng ${ }^{1, a}$ \\ ${ }^{1}$ Pingxiang University, Pingxiang, Jiangxi, China, 337055 \\ aemail,
}

Keywords: Solar Technology, Ecological Building, Application

\begin{abstract}
Green buildings needs to use green renewable energy. Solar energy is one of the largest green energy storage. Therefore, the application of solar energy plays an important role in green building. From the solar energy resources and application current situation of solar energy, this paper highlights the solar technology can be used in green building at this stage and do the necessary analysis on different forms of applications.
\end{abstract}

\section{Introduction}

Energy development is inseparable from human existence. With the rapid development of the economy, a sharp increase in population, human consumption have also shown increasing trend, but the traditional energy sources are becoming depleted. Faced with the shortage of energy resources, environmental pollution, reduce energy consumption society imminent. According to statistics, the international building energy consumption accounts for $40 \%$ of total energy consumption of the human society. Building energy consumption energy power mainly from traditional oil, coal, natural gas, how to reduce energy consumption, building energy efficiency has become a hot research in today's issue of energy, construction, environment and other fields. Also seek green energy instead of traditional conventional energy, ease the energy crisis is also the current energy development focus from the source point.

Ecological building is one of today's most promising architectural form and charm, is the best choice on the road facing the development of construction. In ecological architecture design and implementation process, the application-related technology is a key issue, of which solar energy is one of the most promising technologies. The above article discusses the problem of ecological construction, state of the art solar energy and its applications at home and abroad, Problems and Prospects.

\section{The Concept of Ecological Architecture}

Ecological building concept is the human importance of ecological balance of nature extends in the construction field, which reflects the harmony between man and the natural environment of interdependence. The so-called ecological building, with ecological principles and methods, people, architectural, natural and social development as the goal, sparingly use and transform nature, to find the most suitable for human survival and development of eco-architecture environment, the built environment as a organic, whole system has to look at the structure and function. View from the human ecological building multi-dimensional nature of departure, trying to extend the principle of natural ecosystems to use a wider range of people - environment system. Here the so-called man environment system in the "environment" concept including natural and artificial environment. The people, the natural environment, the built environment regarded as a complete "ecosystem" in the system, focusing on people's "ecological environment," study about people's "ecological factors." In the course of the study, as much as possible the human multiple attributes (physical, mental) inclusive to all people --- Environmental System. Ecological building is a metaphor and it refers to the ability to "ecological" nature, that is, to adapt to the basic law of natural ecological virtuous circle of a class of building.

Ecological building in energy consumption and minimizing use of natural renewable energy sources, such as solar, wind, geothermal, and less consumption of coal, oil and other fossil fuels. 
Architectural design, the construction process as much as possible the use of technology to achieve a comfortable interior environment, and less use of power equipment to meet human needs; on land use, occupation of land as little as possible; emphasizes four in the use of building materials on the "+" principle: reduce, reuse, and regeneration cycle principle. In short, the connotation of ecological architecture can be attributed to: people-oriented, save resources, save energy and protect the environment. It overall orderliness, recycling, feedback balanced, hierarchical stepwise green technology and other features to ensure the sustainable development of the human environment, so as to achieve real harmony between man and nature.

\section{Utilization Status of Solar Energy Technology in Chinese}

China has become the world's acknowledged big country solar energy, the production of only 1998. China solar water heaters have 4 million $\mathrm{m} 2$. Now one thousand domestic solar energy enterprises on the scale, output value of over ten million RMB has been more than 110. 2001 solar vacuum tube collector output of 1000 million, the solar energy industry output value reached 9.8 billion $\mathrm{RMB}$, and is growing at $20 \%$ per year growth rate in the rapid increase in. In particular, our highly efficient all-glass vacuum tube independent intellectual property rights, as well as dual heat pipe vacuum tube end opening of the metal tube, such as development and production of mature high-performance solar collector, greatly promoted the development of China's solar energy industry. Our country has more mature technology in many aspects of solar water heating systems and solar air collector, solar houses and solar thermal utilization of some materials, for the use of solar energy in green buildings provide a strong technical assurance.

Application of solar energy construction began in the late 1970s. Research work was passive and active solar house at the same time start. Because passive solar house is more suited to national conditions, so in the 1980s focused on the development of passive solar houses. The past 20 years, passive solar house made a lot of research results, and some have been put into practical use, get good social and economic benefits.

Our first building passive solar house built in 1977, the point in Minqin County of Gansu Province. This is a south window and direct benefits combined entity collectors' modular solar thermal storage room wall. From 1977 to 198710 years, China built an experimental solar house and passive solar heating demonstration buildings nearly 400, with a total construction area of nearly 100,000 m2, located in Beijing, Tianjin, Gansu, Qinghai, Tibet and other provinces. These solar house building type, the majority of rural housing, but also including schools, office buildings, shops, hotels and urban residential, covering almost all civil construction except industrial buildings other than single-layer and multi-storey buildings , as well as our cave with typical geographical features and the like. By the end of 1996, China has built different types of passive solar houses 15000, total construction area of 4.55 million m2 or more.

Now, our passive solar houses have entered the scale and universal stage. Mainly in order to improve the indoor comfort as the goal, by individual solar building the solar residential quarters, Sun Village, Sun City development. In particular, the relative lack of conventional energy sources, more serious environmental pollution in the western region, more rapid pace of development in some areas an average annual rate of $15 \%$. Localities have also developed a plan to promote solar architecture sunlight, such as investment amounting to 428 million RMB in Lanzhou City, "Sunshine", it plans to build in the suburbs of 733,000 $\mathrm{m} 2$ of solar residential quarters and so on.

Practice has proved that the solar cell, and all kinds of advanced solar house can greatly save conventional energy, reduce emissions of various pollutants, showing the broad application prospects.

\section{The Solar Technology}

The last three decades, developed countries and some developing countries have attached great importance to the development of solar technology. Current solar technology in ecological buildings is mainly in solar thermal and photovoltaic technology technical aspects. By solar thermal, 
photovoltaic conversion can provide daily needs for building energy. The basic principle of solar thermal technology is the solar radiation collected and the light energy is converted into heat energy to be used. Direct application methods are: the use of solar water heaters provide hot water; use of solar collectors for heating or air-dried goods; use solar-heated hot air generated by reinforced building ventilation; a collector using heat storage indirect heating principle of passive solar house. At present solar thermal technology in greenhouse vegetables, herbs and fruit drying and solar water heaters and other applications more mature, extensive, and several other technology because of one-time investment is large, large-scale promotion in the market there are still some limitations. Indirect methods are mainly applied: solar energy absorption or adsorption or jet cooling. But more for the research stage, and some make only a prototype, and production has not been established.

Solar photovoltaic technology, the photovoltaic power generation, is the application of semiconductor devices, namely solar cells convert solar energy into electrical energy by battery storage, and then released under the control of a discharge controller, the need for technical interior lighting. Solar photovoltaic system consists of solar cells, charge and discharge controller, consisting of batteries, load and other parts. The technology is safe and reliable, no noise, no pollution, no fuel, no mechanical moving parts and other advantages. Further solar pump system, the photovoltaic pump also began construction on the application, the system is ideal set of economic, reliability and environmental benefits as one of the green energy system, in the sun-rich areas, especially in remote areas without electricity shortage this is the most attractive way of water supply.

\section{The Solar Technology Can Be Applied in the Ecological Building}

At present, China's actual situation and the capacity of the residents, the high cost of photovoltaic technology, is not yet suitable for use in building energy efficiency, the use of solar thermal in buildings, especially in the use of solar energy for heating, air conditioning and hot water supply as the main way, it is also an effective way to use solar energy EEB be.

Eco energy center building is to solve the problem of pressure building on the environment, therefore, reduce the cooling and heating load of the building, the total electricity load and to minimize the use of renewable energy is fundamental.

Using the New Building Materials. In our country, "Nine Five" plan and the 2010 development plan for building energy efficiency put forward new demands to the implementation of building energy efficiency target of 50\%. Obviously, to achieve this objective, the choice of a new type of building materials is necessary. In green building, in addition to energy conservation, but also requires natural comfort and health properties, which is no doubt building a higher demand. Which requires the production of building materials used in low energy consumption, low pollution; the use of harmony with the environment when discarded easy consumptive or biodegradable, no adverse effects on the environment; should also have the natural energy conversion, storage and other functions.

The Walls and Roofing Materials. In the high-performance concrete frame structure premise, non-load bearing walls should choose a light, insulation, thermal insulation, sound absorption, thermostat functions such as wall materials, such as clay hollow bricks, concrete hollow bricks, aerated concrete ceramic wall, GRC (fiber-reinforced cement) siding, GRC- polystyrene (and perlite) composite insulation panels, rigid mineral wool board, aluminum panels, ceramic blocks, cement foam polystyrene concrete, gypsum block, gypsum board, color steel polystyrene or polyurethane foam type wall panels, rock wool board, silk panels and so on. These materials have advantages and disadvantages, as the case may choose to use.

The Windows. Building doors and windows, exterior walls, roof and floor of the four main parts of the building energy consumption, and the doors and windows topped the list, accounting for $40 \%$ to $50 \%$ of the building envelope heat loss of the structure, an area accounting for the building envelope $30 \%$ of the construction area, accounting for a large proportion in the whole building energy consumption.

Traditional doors and windows sealed well, the thermal conductivity of the material is too large. 
In order to improve its thermal insulation, the choice of steel or steel composite insulation doors and windows, aluminum doors and windows energy-saving steel or glass doors and windows. Such doors have advantages in energy-saving insulation aluminum doors and windows (also known as plastic aluminum doors and windows), for example, it is injecting a PU resin (polyamide plastic partition) in ordinary aluminum extrusions, aluminum window profiles in order to empty cavity filled, prevent heat conduction. When used with IG in the form of its thermal conductivity K value by ordinary aluminum doors and windows $5.93 \mathrm{~W}(\mathrm{~m} 2 \cdot \mathrm{K})$ can be reduced to $2.94 \mathrm{~W}(\mathrm{~m} 2 \cdot \mathrm{K})$, make the room warm in winter and summer air conditioning and refrigeration energy saving over $40 \%$ energy saving effect is obvious. Meanwhile, in the winter when the temperature difference reaches $50{ }^{\circ} \mathrm{C}$, windows and doors will not produce condensation, noise performance is maintained at between $30 \sim 40 \mathrm{~dB}$. Glass doors and windows, as the case may be the choice of single glass, double insulating glass or double vacuum glass, but also add a transparent honeycomb insulating material between the double walls. Glass surface can be coated LOW-E (low emissivity) coating, which can penetrate $80 \%$ of visible light, but also to the more than $90 \%$ longer wavelength infrared radiation and reverse back to the room to prevent the indoor heat radiated outward than traditional doors and windows insulation properties increased by 5 to 8 times. A good way to paste a titanium foil film on the surface of ordinary clear glass doors and windows are also energy efficient, it may reflect a considerable amount of solar heat radiation, and thus greatly reduce the indoor air conditioning and refrigeration energy consumption, and can be saving about 30\%. Moreover, the titanium foil membrane technology is also applicable to high-rise glass curtain wall, glass curtain wall to make strength increases, not broken, not scattered, and there are advantages to block ultraviolet and anti-aging.

\section{Conclusion}

Based on solar thermal hot water, heating, ventilation and air-conditioning technology in full use of natural energy sources, based on artificial energy as a reasonable supplement, both energy-saving, but also can improve the indoor thermal environment, it is eco-building energy technology the core content, while an important part of modern eco-technology system. It is its strong eco-building eco-technology system to support the health and comfort of the occupants with a virtuous cycle of ecological properly combined, fully embodies the harmonious coexistence between humans and nature.

\section{Acknowledgements}

Fund Project: Pingxiang City 2014 Municipal Guiding Science and Technology Projects (2014GY097)

\section{References}

[1] Wang Ruzhu. Reflections on building energy efficiency and solar energy system complex Sinica, 2012, 23 (3): 322 - 335

[2] Wang Zhifeng, Xiahong De, Ding Dewen eco-energy building system (on) Solar, 2011, (4): 2-4

[3] Qi Zhengxin, Lu Yajun, Shi Lei experimental study of solar assisted heat source and low temperature radiant floor heating energy-saving technologies, 2011,19 (108): 2-4

[4] Yan Hongliang. The building envelope structure outlined saving doors and windows energy-saving technologies, 2012, (2): 25-26

[5] Yin Zhiqiang, The solar energy applications in building solar energy, 2008, (2): 9 